\title{
Letter to the editor: Do coagulase-negative staphylococci have no effect on the milk composition of infected mammary gland? A comment on Tomazi et al. (2015)
}

\author{
Nissim Silanikove,${ }^{* 1}$ Uzi Merin, $†$ and Gabriel Leitner \\ *Biology of Lactation Laboratory, Institute of Animal Science, and \\ †Department of Food Quality and Safety, Postharvest and Food Sciences, A.R.O., the Volcani Center, PO Box 6, Bet Dagan 50250, Israel \\ $\ddagger$ National Mastitis Center, Kimron Veterinary Institute, PO Box 12, Bet Dagan 50250, Israel
}

Strains of CNS are the main bacterial species causing infection of the mammary gland in dairy cows, goats, and sheep (Silanikove et al., 2014a). Recently, Tomazi et al. (2015) published a paper showing that apart from a modest increase in SCC, infection with CNS had no effect on milk yield or milk composition of the infected glands compared with uninfected glands. Although we cannot argue with the data itself, we think that simple adoption of the implication of this study might be associated with dissemination of an erroneous concept regarding the importance of CNS infection in dairy cow husbandry.

In the introduction, Tomazi et al. (2015) state, "To our knowledge, no study has reported the effect of IMI caused by CNS on milk yield and composition by comparison of healthy and infected contralateral mammary quarters." The results of Leitner et al. (2006, 2011) and Silanikove et al. (2014b) report on the effect of infection with CNS by comparing noninfected and infected contralateral mammary quarters in dairy cows, and similar studies have been carried on in sheep and goats (Silanikove et al., 2014a). Those results clearly show that infection of a single mammary gland with CNS is associated with significant changes in milk composition in the infected gland compared with the uninfected gland. Most notably, infection was associated with a significant increase in casein degradation due to increased plasmin activity (Leitner et al., 2006, 2011). The increased casein degradation was associated with poorer clotting parameters as reflected by lower curd firmness and increased rennet clotting time, consistent with similar findings in goats and sheep (Leitner et al., 2011; Silanikove et al., 2014a). In contradiction to the finding of Tomazi et al. (2015), the reduction in lactose concentration in infected glands was highly significant compared with that in the uninfected glands

Received June 7, 2015.

Accepted August 4, 2015.

${ }^{1}$ Corresponding author: nsilanik@agri.huji.ac.il
$(P<0.0091$ in Leitner et al., 2006; $P<0.001$ in Leitner et al., 2011; Silanikove et al., 2014b), and models that explained the interrelationship between reduction in lactose concentration and decrease in milk quality for curdling were presented and discussed (Leitner et al., 2011; Silanikove et al., 2014b). To complete the picture, it should be noted that mixing bacterially contaminated milk with milk from noncontaminated glands negatively affects the clotting parameters of the uninfected milk (i.e., of the mixture; Silanikove et al., 2014a), and such mixing may explain the variability in milk quality for curdling at the level of dairy farm bulk tank (Leitner et al., 2008).

In conclusion, the effect of CNS on milk production at the whole-cow level is relatively small $(\sim 5 \%$; Silanikove et al., 2014b) or absent (see Schukken et al., 2009, cited in Tomazi et al., 2015). The lack of a significant reduction in milk yield results from dilution of the lesser yield of a single gland and compensation of milk yield increase by the other uninfected glands (Silanikove et al., 2014a,b). However, the effect of CNS infection on milk quality for cheese production is not compensable and may negatively affect the milk quality of bacteria-free milk. As the use of dairy cow milk for cheese production represents a significant proportion of milk production (about 40\%), we hope that this letter will raise awareness and encourage researchers to consider the effect of CNS on milk quality in future studies.

\section{REFERENCES}

Leitner, G., O. Krifucks, U. Merin, Y. Lavi, and N. Silanikove. 2006. Interactions between bacteria type, proteolysis of casein and physico-chemical properties of bovine milk. Int. Dairy J. 16:648-654. http://dx.doi.org/10.1016/j.idairyj.2005.10.020.

Leitner, G., U. Merin, and N. Silanikove. 2011. Effects of glandular bacterial infection and stage of lactation on milk clotting parameters: Comparison among cows, goats and sheep. Int. Dairy J. 21:279-285. http://dx.doi.org/10.1016/j.idairyj.2010.11.013.

Leitner, G., N. Silanikove, S. Jacobi, L. Weisblit, S. Bernstein, and U. Merin. 2008. The influence of storage on the farm and in dairy silos on milk quality for cheese production. Int. Dairy J. 18:109-113. http://dx.doi.org/10.1016/j.idairyj.2007.09.001. 
Schukken, Y. H., R. N. Gonzalez, L. L. Tikofsky, H. F. Schulte, C. G. Santisteban, F. L. Welcome, G. J. Bennett, M. J. Zurakowski, and R. N. Zadoks. 2009. CNS mastitis: Nothing to worry about? Vet. Microbiol. 134:9-14.

Silanikove, N., U. Merin, F. Shapiro, and G. Leitner. 2014a. On effects of subclinical mastitis and stage of lactation on milk quality in goats. Small Rumin. Res. 122:76-82. http://dx.doi.org/10.1016/j. smallrumres.2014.07.018.

Silanikove, N., U. Merin, F. Shapiro, and G. Leitner. 2014b. Milk metabolites as indicators of mammary gland functions and milk quality. J. Dairy Res. 81:358-363. http://dx.doi.org/10.1017/ S0022029914000260.

Tomazi, T., J. L. Gonalves, J. R. Barreiro, M. A. Arcari, and M. V. dos Santos. 2015. Bovine subclinical intramammary infection caused by coagulase-negative staphylococci increases somatic cell count but has no effect on milk yield or composition. J. Dairy Sci 98:3071-3078. http://dx.doi.org/10.3168/jds.2014-8466. 